\title{
PENGARUH PROFITABILITAS, STRUKTUR AKTIVA, DAN LIKUIDITAS TERHADAP STRUKTUR MODAL PERUSAHAAN SUBSEKTOR KONSTRUKSI BANGUNAN DI BEI
}

\author{
Ni Putu Yulinda Prastika ${ }^{1}$ \\ Made Reina Candradewi ${ }^{2}$ \\ ${ }^{1,2}$ Fakultas Ekonomi dan Bisnis Universitas Udayana (Unud), Bali, Indonesia \\ E-mail: lindaprastika@gmail.com
}

\begin{abstract}
ABSTRAK
Penelitian ini bertujuan untuk mengetahui faktor-faktor penting yang dapat mempengaruhi struktur modal perusahaan sub sektor konstruksi bangunan di Bursa Efek Indonesia (BEI). Terdapat 3 (tiga) faktor penting yang dapat mempengaruhi struktur modal yakni: profitabilitas, struktur aktiva, dan likuiditas. Penelitian ini menggunakan purposive sampling dalam metode penentuan sampel sehingga mendapatkan 9 perusahaan yang menjadi sampel penelitian ini. Data yang digunakan dalam bentuk data sekunder yang diambil selama 6 tahun pada periode 2012-2017. Regresi linear berganda sebagai teknik analisis data yang digunakan. Hasil yang didapatkan dari penelitian ini adalah 1) variabel profitabilitas berpengaruh negatif signifikan terhadap struktur modal perusahaan sub sektor konstruksi bangunan di Bursa Efek Indonesia (BEI); 2) struktur aktiva berpengaruh negatif dan signifikan terhadap perusahaan sub sektor konstruksi bangunan di BEI; dan 3) likuiditas berpengaruh negatif signifikan terhadap struktur modal perusahaan sub sektor konstruksi bangunan di BEI.
\end{abstract}

Kata kunci: struktur modal, profitabilitas, struktur aktiva, likuiditas

\begin{abstract}
This study aims to determine the important factors that can affect the capital structure of companies in the construction construction sub-sector on the Indonesia Stock Exchange (IDX). There are 3 (three) important factors that can affect the capital structure, namely: profitability, asset structure, and liquidity. This research uses purposive sampling in the method of determining the sample so that it gets 9 companies which are the samples of this study. Data used in the form of secondary data taken for 6 years in the period 2012-2017. Multiple linear regression as a data analysis technique used. The results obtained from this study are 1) variable profitability has a significant negative effect on the capital structure of the company's construction construction sub-sector on the Indonesia Stock Exchange (IDX); 2) asset structure has a negative and significant effect on the building construction sub-sector of the company on the IDX; and 3) liquidity has a significant negative effect on the capital structure of the company's construction construction sub-sector on the IDX.

Keywords: capital structure, profitability, asset structure, liquidity
\end{abstract}




\section{PENDAHULUAN}

Globalisasi yang semakin berkembang ditandai dengan dunia bisnis yang semakin meningkat. Persaingan antar perusahaan menjadi semakin ketat menyebabkan perusahaan terdorong untuk meningkatkan kinerja keuangan perusahaan. Perusahaan memerlukan modal untuk melakukan operasi dan pengembangan usahanya. Pengembangan usaha akan dilakukan oleh perusahaan yang kecil sampai ke perusahaan yang besar. Modal yang diperlukan untuk pengembangan usaha dapat berasal dari dalam perusahaan, hal ini akan memberikan kemandirian secara finansial dari perusahaan tersebut karena perusahaan mampu memenuhi kebutuhan dananya tanpa bantuan dari pihak eksternal. Penambahan modal yang berasal dari pihak eksternal bisa digunakan ketika perusahaan telah menggunakan seluruh dana internalnya dan memerlukan tambahan dana untuk pengembangan usaha.

Fungsi manajemen keuangan perusahaan meliputi tiga keputusan penting. Keputusan tersebut terdiri dari pengambilan keputusan investasi, pengambilan keputusan pendanaan, dan kebijakan dividen (Sartono, 2014). Keputusankeputusan penting yang akan diambil oleh perusahaan akan membantu perusahaan dalam mencapai tujuan dalam mengatur keuangan. Tujuan yang dicapai oleh perusahaan meliputi memaksimumkan nilai perusahaan, menjaga stabilitas finansial dalam keadaan yang selalu terkendali, dan memperkecil risiko perusahaan dimasa sekarang dan yang akan datang (Fahmi, 2018). Kariyoto (2018) menyatakan bahwa manajer keuangan sebuah perusahaan harus bekerjasama dengan manajer pada lini lainnya. 
Struktur modal (capital structure) adalah perimbangan jangka panjang yang menunjukkan perbandingan antara hutang jangka panjang dan modal sendiri yang digunakan oleh perusahaan (Wangsawinangun, 2014). Perbandingan ini yang disebut dengan DER (debt to equity ratio), rasio ini mampu mengambarkan struktur modal perusahaan. Struktur modal atau permodalan perusahaan adalah pembiayaan permanen yang terdiri dari hutang jangka panjang, saham preferen, dan modal pemegang saham (Musthafa, 2017, p. 89).

Perusahaan yang sedang dalam proses penyusunan struktur modalnya dapat menerbitkan saham baru. Penerbitan saham akan menghasilkan dana tambahan dari pemegang saham yang dapat digunakan perusahaan sehingga struktur modal perusahaan menjadi lebih baik (Samsul, 2016, p. 68). Anggiani (2018, p. 167) menyatakan bahwa seluruh keputusan yang diambil oleh perusahaan untuk mendapatkan modal memiliki dampaknya masing-masing. Berbagai perimbangan yang dilakukan oleh manajer keuangan, dilakukan untuk mencari struktur modal seperti apa yang nantinya akan digunakan digunakan oleh perusahaan.

Biaya-biaya yang akan timbul akibat dari pemenuhan modal perusahaan dapat bersifat eksplisit maupun biaya implisit yang harus dibayar oleh perusahaan atau keuntungan yang diisyaratkan oleh pemodal. Biaya kesempatan (opportunity cost) inilah yang menyebabkan timbulnya biaya modal yang bukan merupakan biaya tunai. Perusahaan perlu cermat dalam menentukan struktur modal optimal yang digunakan oleh perusahaan, dengan tujuan mengurangi risiko likuiditas.

Posisi keuangan perusahaan mendapatkan dampak apabila struktur modal perusahaan dalam keadaan baik maupun buru (Damayanti, 2017). Konsep dari cost 
of capital menyatakan bahwa struktur modal yang optimum adalah struktur modal yang dapat meminimumkan biaya penggunan modal rata-rata (average cost of capital) (Musthafa, 2017). Dampak dari perubahan biaya modal tersebut akan mempengaruhi keputusan anggaran modal dan harga saham perusahaan pun ikut terpengaruhi, sehingga penting untuk mengetahui alasan dibalik alternatif yang ada untuk memahami pilihan dari struktur modal (Chiang et al., 2010).

Perusahaan sub sektor konstruksi bangunan membutuhkan dana external untuk menambah modal serta sebagai penunjang kepercayaan masyarakat dan pemerintah pada perusahaan. Penambahan modal eksternal perusahaan dapat dicari dengan melakukan pinjaman pada kreditor atau dengan melakukan listing di Bursa Efek Indonesia. Perusahaan yang bergerak dibidang subsektor konstruksi bangunan harus menentukan struktur modal optimum untuk pemanfaatan aktiva dan pengelolaan keuangan kedepannya. Pada Tabel 1 telah disajikan mengenai persentase DER dari perusahaan subsektor konstruksi bangunan yang terdaftar di BEI.

Tabel 1.

Debt to Equity Ratio dari 9 Perusahaan Subsektor Konstruksi Bangunan

\begin{tabular}{lrrrrr}
\multicolumn{7}{c}{ Periode 2012-2017 } \\
\hline Tahun & 2012 & 2013 & 2014 & 2015 & 2016 \\
\hline Tertinggi & $567 \%$ & $528 \%$ & $511 \%$ & $274 \%$ & $269 \%$ \\
Terendah & $75 \%$ & $98 \%$ & $85 \%$ & $84 \%$ & $87 \%$ \\
Rata-rata & $278 \%$ & $249 \%$ & $242 \%$ & $184 \%$ & $165 \%$ \\
\hline S & & & & &
\end{tabular}

Sumber: Data diolah, 2018

Berdasarkan Tabel 1 dapat dilihat bahwa perusahaan sub sektor konstruksi bangunan dengan struktur modal yang diproyeksikan dengan DER memiliki persentase struktur modal yang mengalami fluktuasi setiap tahunnya. Perusahaan sub sektor konstruksi bangunan yang memiliki DER tertinggi mampu melebihi 
Ni Putu Yulinda Prastika, Pengaruh Profitabilitas, Struktur...

$100 \%$ menandakan perimbangan permodalan perusahaan lebih menggunakan liabilitasnya dibandingkan ekuitas. Tingkat DER perusahaan juga mampu berada dibawah 100\%, ini menunjukkan bahwa perusahaan lebih menggunakan dana internalnya dibandingkan dengan dana yang berasal dari eksternal perusahaan.

Terdapat dua pembagian dari struktur modal secara garis besar yakni dengan sepenuhnya menggunakan modal sendiri dan perpaduan antara modal sendiri dan modal pinjaman. Dua pembagian inilah kemudian dilakukan kajian secara komperehensif manakah yang paling tepat dipergunakan berdasarkan situasi dan kondisi internal dan eksternal perusahaan (Fahmi, 2018). Analisis yang dilakukan terhadap faktor-faktor penentu struktur modal bertujuan agar perusahaan dapat mengevaluasi kinerja perusahaan.

Faktor-faktor yang dapat mempengaruhi struktur modal adalah stabilitas penjualan, struktur aktiva, leverage keuangan, tingkat pertumbuhan perusahaan, profitabilitas, pajak, pengendalian, sikap manajemen, sikap pemberi pinjaman dan lembaga pemeringkat, kondisi pasar, kondisi internal perusahaan, dan fleksibilitas keuangan (Brigham \& Houston, 2016). Penelitian yang dilakukan oleh Deesomsak et al. (2004), Alipour et al. (2015), Vo (2017) mengemukakan beberapa faktorfaktor penting yang dapat mempengaruhi struktur modal suatu perusahaan adalah profitabilitas, struktur aktiva, dan likuiditas. Faktor-faktor ini menunjukkan kemampuan perusahaan dalam mengolah aktiva yang dimilikinya untuk mendapatkan dana pada investasinya.

Faktor pertama yang dapat mempengaruhi struktur modal adalah profitabilitas Septiono dkk. (2012), mengemukakan profitabilitas merupakan 
kemampuan perusahaan untuk memperoleh laba atau profit. Setiap operasional perusahaan, yang menjadi tujuan utama dari usahanya yaitu mencari keuntungan atau profitabilitas. Semakin besar keuntungan perusahaan, semakin besar laba ditahan yang mampu untuk digunakan dalam operasionalnya. Pilihan utama perusahaan dalam memilih pembiayaan adalah laba ditahan sehingga meningkatkan struktur modal akan menyebabkan penggunaan hutang akan semakin rendah (Farisa \& Widati, 2017). Salah satu alat ukur yang dapat digunakan untuk mengukur profitabilitas perusahaan adalah Return On Assets (ROA).

Penelitian yang dilakukan oleh Nugroho (2014) hasil penelitian menunjukkan variabel profitabilitas berpengaruh positif signifikan terhadap struktur modal. Kesuma (2009) menyatakan perbedaan hasil penelitian, dimana profitabilitas mempunyai pengaruh berlawan arah dengan struktur modal. Hasil penelitian Utami (2017) profitabilitas berpengaruh negatif terhadap struktur modal.

Struktur aktiva merupakan faktor penting kedua yang dapat mempengaruhi struktur modal. Struktur aktiva adalah adalah kekayaan atau sumber-sumber ekonomi yang dimiliki perusahaan dan yang terdiri dari aktiva tetap dan aktiva lancar, diharapkan memberikan manfaat dimasa yang akan datang (Kesuma, 2009). Struktur aktiva merupakan salah satu variabel penting dalam perusahaan untuk menentukan salah satu keputusan keuangan yang diambil perusahaan yakni keputusan pendanaan. Kepakisan (2015) menyatakan bahwa struktur aktiva berhubungan dengan jumlah kekayaan (aktiva) yang dapat dijadikan jaminan. Perusahaan perlu memberikan jaminan pada kredutur untuk meyakinkan kredibilitas perusahaan. Struktur aktiva yang tinggi dan digunakan untuk jminan ini 
dapat digunakan perusahaan untuk meningkatkan dana perusahaan yang berasal dari eksternal (hutang).

Komposisi aktiva tetap berwujud perusahaan yang jumlahnya besar akan mempunyai peluang untuk memperoleh tambahan modal dengan hutang, karena aktiva tetap dapat dijadikan sebagai jaminan untuk memperoleh hutang (Batubara, Topowijono, \& Z.A., 2017). Semakin tinggi struktur aktiva perusahaaan, menunjukkan semakin tinggi kemampuan dari perusahaan tersebut untuk dapat menjamin hutang jangka panjang yang dipinjamnya. Menurut Bambang (2008) perusahaan yang sebagian besar aktivanya berasal dari aktiva tetap akan mengutamakan pemenuhan kebutuhan dananya dengan utang. Perusahaan dengan jumlah aktiva tetap yang besar dapat menggunakan utang lebih banyak karena aktiva tetap dapat dijadikan jaminan yang baik atas pinjaman-pinjaman perusahaan.

Dewi (2014) menyatakan bahwa tangibility assets berefek positif dan signifikan terhadap struktur modal. Penelitian sejalan oleh Cahyani (2017), mendapatkan hasil struktur aset berpengaruh positif terhadap struktur modal. Hasil penelitian yang berbeda ditemukan oleh Sansoethan (2016) yang menyatakan struktur aset mempunyai pengaruh negatif dan secara parsial berpengaruh signifikan terhadap struktur modal. Liestyasih (2015) menyimpulkan struktur aktiva berpengaruh negatif signifikan terhadap struktur modal.

Faktor ketiga yang dapat mempengaruhi struktur modal adalah likuiditas. Likuiditas merupakan tingkat kemampuan perusahaan dalam memenuhi kewajiban jangka pendeknya dengan aset lancar yang tersedia (Wiagustini, 2014). Perusahaan perlu pengaturan, menjaga dan memelihara likuiditas yang baik untuk menjaga 
kredibilitas kepada kreditur karena perusahaan yang tidak likuid merupakan perusahaan yang tidak sehat (Dewi \& Dana, 2017). Likuiditas menyangkut kebijakan manajemen dalam membentuk aktiva lancar terutama kas dan marketable securities yang dikuasai oleh perusahaan, kebijakan tersebut meliputi kebijakan seberapa besar investasi harus dilakukan pada kategori aktiva lancar bagaimana investasi tersebut harus dibiayai (Utami \& Widanaputra, 2017). Perusahaan yang mempunyai likuiditas tinggi berarti mempunyai kemampuan membayar hutang jangka pendek, sehingga cenderung akan menurunkan total hutang, yang akhirnya struktur modal akan menjadi lebih kecil (Armelia \& Ruzikna, 2016).

Hasil penelitian yang dilakukan oleh Irdiana (2016) likuiditas mempunyai pengaruh yang positif dan signifikan terhadap struktur modal. Deviani (2018) menyatakan bahwa likuiditas memiliki pengaruh negatif dan signifikan terhdap struktur modal. Berbeda dengan penelitian yang dilakukan oleh Bhawa (2015) likuiditas berpengaruh positif signifikan terhadap struktur modal.

Berdasarkan uraian latar belakang dan adanya perbedaan hasil penelitian terdahulu, maka penelitian ini lebih lanjut menganalisis hubungan antar variabel profitabilitas, struktur aktiva, likuiditas, dan struktur modal serta jauhnya rentang perbedaan persentase DER setiap tahunnya dari perusahaan subsektor konstruksi dan bangunan pada Tabel 1 menyebabkan variabel-variabel ini layak dan menarik untuk diteliti kembali dengan judul "Pengaruh Profitabilitas, Struktur Aktiva, dan Likuiditas terhadap Struktur Modal Perusahaan Subsektor Konstruksi Bangunan yang Terdaftar Di BEI". 
Keputusan pembiayaan berkaitan dengan komposisi dari proporsi relatif berbagai sumber dana. Komposisi ini mencakup mengenai proporsi modal dan hutang dalam struktur modal. Sumber pendanaan dianalisis untuk memiliki biaya yang rendah seperti risiko yang ditimbulkannya. Keputusan ini menentukan keseluruhan biaya modal dan risiko finansial sebuah perusahaan (Tulsian \& Tulsian, 2016, p. 9). Sumber dana yang berkaitan dengan keputusan pembiayaan terdiri dari sumber dana menurut asalnya dan sumber dana menurut jangka waktunya (Wiagustini, 2014).

Sumber dana yang dapat dipilih oleh perusahaan memiliki beragam jenis. Menurut Tulsian (2016, p. 9) tujuan dari keputusan pendanaan adalah untuk memutuskan sumber yang akan digunakan perusahaan untuk membiayai keputusan investasi perusahaan. Faktor yang dapat mempengaruhi dari keputusan pendanaan ini adalah risiko, biaya, kontrol, leverage keuangan, kemampuan arus kas, fleksibilitas, kondisi pasar, biaya flotasi, dan kerangka hukum.

Struktur modal (capital structure) adalah perpaduan sumber dana jangka panjang (long-term sources of funds) yang digunakan perusahaan untuk mencapai tujuan perusahaan dalam memaksimumkan kekayaan pemegang saham. Manajer keuangan harus dapat menilai struktur modal dan memahami hubunganya dengan risiko, hasil atau pengembalian nilai. Struktur modal pada jangka waktu yang lama, dianggap sebagai area teknikal yang melibatkan satu atau dua karyawan untuk perusahaan menengah. Pebisnis yang masih tradisional, area ini tidak dapat menghasilkan penghasilan signifikan dibandingkan dengan area keuangan lainnya seperti pemilihan proyek investasi yang paling baik (Miglo, 2016, p. 3). 
Pentingnya keputusan struktur modal karena perusahaan perlu untuk memaksimisasi return dari perusahaan dan berdampak pada kemampuan perusahaan untuk mampu berkompetisi dalam lingkungan bisnis yang kompetitif (Gill \& Biger, 2011). Menurut Madhavilata (2016) menyatakan bahwa dengan struktur modal yang efisien, perusahaan yang terpilih dapat mengutilitas kapasitas optimalnya. Seluruh faktor tersebut memberikan peran, tapi analisis akhir dari dampak struktur modal terhadap nilai perusahaan secara keseluruhan harus dianggap sebagai hal yang penting. Meningkatkan nilai perusahaan secara keseluruhan akan meningkatkan harga saham (sesungguhnya), dan kesejahteraan pemegang saham (De Wet, 2006).

Peningkatan risiko akan meningkatkan tingkat kebangkrutan yang bisa saja akan mengurangi minat investor untuk menanamkan modalnya, sehingga harga saham perusahaan akan cenderung untuk menurun. Tingginya return yang diberikan perusahaan kepada investor maka akan meningkatkan harga saham. Permintaan pasar terhadap saham perusahaan yang akan meningkat karena return yang diberikan mampu mensejahterakan investor.

Struktur modal yang optimum atau paling tidak terletak dalam suatu rentang tertentu untuk suatu perusahaan menentukan seberapa besar perusahaan menggunakan hutang dan seberapa besar perusahaan menggunakan modal sendiri yang dapat bergantung pada kondisi perusahaan. Perbedaan kondisi pada setiap perusahaan yang menyebabkan sulitnya untuk menentukan struktur modal yang optimum secara pasti. 
Ni Putu Yulinda Prastika, Pengaruh Profitabilitas, Struktur...

Teori-teori dari struktur modal bertujuan untuk memberikan landasan berpikir untuk mengetahui bagaimana manajer mengolah faktor-faktor yang dapat mempengaruhi struktur modal yang mampu menghasilkan struktur modal optimal bagi perusahaan tersebut. Suatu struktur modal dapat dikatakan optimal apabila keadaan dimana risiko dan pengembaliannya seimbang sehingga dapat memaksimalkan harga saham perusahaan.

Menurut Fahmi (2018, p. 193) balancing theory merupakan suatu kebijakan yang dibentuk oleh perusahaan dalam pencarian dana tambahan dengan mencari pinjaman melalui perbankan, leasing, atau dengan menggunakan obligasi (bonds). Risiko yang harus ditanggung ketika perusahaan menggunakan kebijakan balancing theory adalah dibutuhkannya jaminan ketika meminjam dana dengan ancaman pengambil alihan aset ketika perusahaan terlambat membayar angsuran kredit.

Perusahaan yang memasuki tahap ketidakmampuan untuk memayar utang obligasi tepat waktu sesuai dengan yang disepakati maka perusahaan harus mengatasi ini dengan melakukan berbagai kebijakan seperti mengonversikan pemegang obligasi menjadi pemegang saham, dan yang terakhir adalah masyarakat akan berfikir perusahaan memiliki citra yang rendah karena struktur modal yang dimiliki perusahaan tidak optimum karena kinerja perusahaan yang rendah.

Peckting order theory merupakan suatu kebijakan yang ditempuh oleh suatu perusahaan untuk mencari tambahan dana dengan cara menjual asset yang dimilikinya. Pecking order theory melibatkan hirarki dimana perusahaan pertama kali menggunakan dana internal mereka, diikuti dengan penerbitan sekuritas jangka 
pendek. Perusahaan dalam hal ini akan cenderung untuk mendanai investasi dengan cash flow yang dihasilkan dari internal dan ekuitas internal. Apabila dibutuhkan dana eksternal, hutang akan dipilih oleh perusahaan dari pada ekuitas karena kurang tunduk pada hasil evaluasi (Abosede, 2012). Teori pecking order menyarankan perusahan memiliki prefrensi dalam memilik sumber pendanaan dengan mempertimbangkan biaya termurah dan risiko yang paling kecil. Pada teori ini tidak terdapat sturktur modal yang optimal.

Pecking order theory menyatakan bahwa perusahaan lebih menyukai sumber dana internal yang besar, sehingga tidak memerlukan hutang yang banyak. Pecking order theory tidak mengindikasikan target struktur modal, namun lebih menjelaskan urutan-urutan pendanaan. Urutan pendanaan berdasarkan teori ini yakni pendanaan internal yang berasal dari laba ditahan merupakan urutan pertama, lalu dilanjutkan dengan penggunaan utang dengan menerbitkan obligasi dan yang terakhir adalah penerbitan saham (Radjamin \& Sudana, 2014). Kebutuhan dana ditentukan oleh kebutuhan investasi.

Profitabilitas didefinisikan sebagai pendapatan dari perusahaan yang ihasilkan dari pendapatan setelah dikurangi semua biaya yang dikeluarkan selama periode tertentu (Alarussi \& Alhaderi, 2018). Perusahaan akan menggunakan utang yang relatif lebih rendah jika perusahaan memiliki tingkat pengembalian atas investasi yang tinggi sehingga memungkinkan perusahaan membiayai sebagian besar kebutuhan pendanaannya dengan dana internal perusahaan (Brigham \& Houston, 2016). Setiap perusaahaan akan mencari cara agar profitnya selalu meningkat. Penelitian ini menggunakan ROA sebagai proxy dari profitabilitas 
Ni Putu Yulinda Prastika, Pengaruh Profitabilitas, Struktur...

dengan tujuan untuk menilai tingkat pengembalian atau profit perusahaan untuk membiayai kebutuhannya yang dihasilkan dari mengutilisasi seluruh aset yang dimilikinya.

Profit perusahaan yang lebih tinggi menyebabkan perusahaan cenderung menggunakan hutang lebih sedikit. Tingginya profit mengingkatkan penggunaan pendanaan internal, sementara profit yang rendah akan menyebabkan perusahaan menggunakan hutang lebih banyak karena pendanaan internalnya tidak mencukupi (Acaravci, 2015). Perusahaan dengan dana internal yang tinggi akan mengurangi minat untuk menggunakan dana yang berasal dari pihak eksternal. Perusahaan yang memiliki tingkat profitabilitas tinggi berarti memiliki tingkat pengembalian hutang dan laba ditahan yang tinggi, maka perusahaan akan cenderung menggunakan laba ditahan dan mengurangi hutang (Bhawa \& Sangging, 2015).

Hasil penelitian yang dilakukan oleh Yusrianti (2013), Acaravci (2015), Bhawa (2015) dan Tijow dkk. (2018) yang menyatakan bahwa profitabilitas berpengaruh negatif terhadap struktur modal perusahaan. Hipotesis yang dapat ditarik adalah:

$\mathrm{H}_{1}$ : Profitabilitas berpengaruh negatif terhadap Struktur Modal pada perusahaan sub sektor konstruksi bangunan di BEI.

Struktur aktiva adalah kekayaan atau sumber-sumber ekonomi yang dimiliki oleh perusahaan yang diharapkan akan memberikan manfaat dimasa yang akan datang (Kesuma, 2009). Perusahaan kecil maupun makro menggunakan jaminan mereka untuk menarik kreditor (Harc, 2015). Besarnya jumlah aktiva tetap dapat digunakan sebagai jaminan hutang perusahaan, maka perusahaan dengan aktiva 
tetap yang tinggi memiliki kesempatan besar dalam mendapatkan hutang jangka panjang (Suweta \& Dewi, 2016).

Penelitian yang dilakukan Perwiti dan Darmayanti (2018), Suweta dan Dewi (2016), Mandana (2011), Suryaman (2016), dan Harc (2015) menyatakan bahwa hubungan antara tangible assets dan struktur modal adalah positif dan berpengaruh signifikan. Berdasarkan pemaparan diatas, hipotesis yang dapat diajukan adalah:

$\mathrm{H}_{2}$ : Struktur aktiva berpengaruh positif terhadap struktur modal pada perusahaan sub sektor konstruksi bangunan di BEI.

Likuiditas adalah kemampuan yang dimiliki perusahaan untuk memenuhi kewajiban jangka pendeknya dengan aset lancar yang dimilikinya. Likuiditas merupakan suatu indikator yang mengukur kemampuan perusahaan untuk membayar semua kewajiban finansial jangka pendek pada saat jatuh tempo dengan menggunakan aktiva lancar yang tersedia (Wiagustini, 2014). Penelitian ini menggunakan rasio lancar (current ratio) sebagai proxy dari likuiditas. Rasio lancar (current ratio) merupakan salah satu rasio finansial yang sering digunakan. Current Ratio merupakan perbandingan antara aktiva lancar dengan hutang jangka pendek. Rasio ini menunjukan kesangupan membayar hutang jangka pendek.

Semakin tinggi likuiditas maka tingkat struktur modal perusahaan akan menurun. Artinya, jika perusahaan yang mempunyai likuiditas tinggi berarti mempunyai kemampuan membayar hutang jangka pendek, sehingga cenderung akan menurunkan total hutang, yang akhirnya struktur modal akan menjadi lebih kecil (Widayanti dkk., 2016). Hasil penelitian dari Widayanti dkk. (2016), Juliantika (2017), dan Novitayanti (2018) menyatakan bahwa likuiditas 
berpengaruh negatif signifikan terhadap struktur modal. Hipotesis yang dapat diajukan adalah:

$\mathrm{H}_{3}$ : Likuiditas berpengaruh negatif terhadap struktur modal pada perusahaan sub sektor konstruksi bangunan di BEI.

\section{METODE PENELITIAN}

Penelitian ini dilakukan pada seluruh perusahaan sub sektor konstruksi bangunan yang terdaftar di BEI dengan cara pengunduhan dokumen laporan keuangan tahunan pada tahun 2012-2017. Objek dalam penelitian ini adalah profitabilitas, struktur aktiva, likuiditas, dan struktur modal pada perusahaan sub sektor konstruksi bangunan di BEI periode 2012-2017.

Rasio ini menunjukkan proposi hutang dan ekuitas perusahaan dalam beroperasi. Struktur modal dengan proxy DER diukur dengan persamaan:

$\mathrm{DER}=\frac{\text { Total Hutang }}{\text { Total Ekuitas }} \times 100 \%$

ROA dinyatakan dalam bentuk persentase dan diukur dengan menggunakan persamaan:

$\mathrm{ROA}=\frac{\text { Earning After } \text { Tax }}{\text { Total } \text { Asset }} \times 100 \%$

Struktur aktiva dapat diukur dengan menggunakan persamaan:

$\mathrm{TANG}=\frac{\text { Aktiva Tetap }}{\text { Total Aktiva }} \times 100 \%$

Data current ratio sebagai proxy dari likuiditas akan berbentuk persentase dan diukur dengan menggunakan persamaan: 
Current Ratio $=\frac{\text { Aset Lancar }}{\text { Hutang Lancar }} \times 100 \%$

Populasi dalam penelitian ini adalah seluruh perusahaan sub sektor konstruksi bangunan di BEI tahun 2017 yang diakses pada yang berjumlah 16 perusahaan. Sampel pada penelitian ini adalah perusahaan sub sektor konstruksi bangunan yang terdaftar di BEI yang memenuhi kriteria yang digunakan untuk menentukan jumlah sampel.

Teknik analisis data yang digunakan dalam penelitian ini adalah teknik analisis regresi linier berganda. Persamaan regresi linier berganda tersebut dinyatakan sebagai berikut:

$\mathrm{DER}=\mathrm{a}+\mathrm{b} 1 \mathrm{ROA}+\mathrm{b} 2 \mathrm{TANG}+\mathrm{b} 3 \mathrm{CR}+\mathrm{e}$

Keterangan :

a $\quad=$ Konstanta

b $\quad$ Koefisien regresi dari masing-masing variabel independen

e $\quad=$ Standart error

$\mathrm{DER}=$ debt to equity ratio

$\mathrm{ROA}=$ Profitabilitas

$\mathrm{CR}=$ Likuiditas

TANG $=$ Rasio Struktur Aktiva (tangibility asset ratio)

\section{HASIL DAN PEMBAHASAN}

Penyajian statistik deskriptif dilakukan untuk menginformasikan karakteristik variabel-variabel penelitian, seperti nilai terkecil, nilai terbesar, rata-rata dan standar deviasi. Berdasarkan hasil statistik deskriptif yang ditunjukkan pada Tabel 2 didapat hasil bahwa sampel yang berjumlah 54 .

Struktur modal perusahaan (DER) memiliki nilai minimum 85,10 pada Nilai maksimum sebesar 382,68 dan mean sebesar 203,49 dengan standar deviasi sebesar 
Ni Putu Yulinda Prastika, Pengaruh Profitabilitas, Struktur...

71,34 artinya terjadi penyimpangan nilai struktur modal perusahaan terhadap nilai rata-ratanya sebesar 71,34. Profitabilitas (ROA) memiliki nilai minimum 0,85 Nilai maksimum sebesar 15,06 dan mean sebesar 5,46 dengan standar deviasi sebesar 3,06 artinya terjadi penyimpangan nilai profitabilitas terhadap nilai rata-ratanya sebesar 3,06.

Tabel 2.

Statistik Deskriptif Data Uji

\begin{tabular}{lcrrrr}
\hline & N & \multicolumn{1}{c}{ Minimum } & Maximum & \multicolumn{1}{c}{ Mean } & Std. Deviation \\
\hline DER & 54 & 85,10 & 382,68 & 203,49 & 71,34 \\
ROA & 54 & 0,85 & 15,06 & 5,46 & 3,06 \\
TANG & 54 & 2,86 & 17,83 & 9,77 & 4,35 \\
CR & 54 & 17,83 & 200,60 & 123,69 & 46,85 \\
Valid N & 54 & & & & \\
(listwise) & & & & &
\end{tabular}

Struktur Aktiva (TANG) memiliki nilai minimum 2,86 Nilai maksimum sebesar 17,83 dan mean sebesar 9,77 dengan standar deviasi sebesar 4,35 artinya terjadi penyimpangan nilai struktur aktiva terhadap nilai rata- ratanya sebesar 4,35. Likuiditas (CR) memiliki nilai minimum 7,48. Nilai maksimum sebesar 200,60 dan mean sebesar 123,69 dengan standar deviasi sebesar 46,85 artinya terjadi penyimpangan nilai likuiditas terhadap nilai rata-ratanya sebesar 46,85.

Analisis ini digunakan untuk memprediksi satu variabel tergantung berdasarkan dua atau lebih variabel bebas. Hasil analisis regresi linier berganda dapat dilihat pada Tabel 3.

Penelitian ini, analisis regresi berganda merupakan alat analisis yang dilakukan untuk mengetahui pengaruh dari profitabilitas, struktur aktiva, dan likuiditas terhadap variable terikat struktur modal. Berdasarkan Tabel 3. dapat 
dibuat persamaan regresi linier berganda sebagai berikut: $\mathrm{DER}=347,89$ $6,395 \mathrm{ROA}-5,342 \mathrm{TANG}-0,436 \mathrm{CR}+31,558$.

Tabel 3.

Hasil Uji Regresi Linier Berganda

\begin{tabular}{llrrr}
\hline & \multicolumn{2}{c}{ Unstandardized Coefficients } & \multicolumn{2}{c}{$\begin{array}{c}\text { Standardized } \\
\text { Coefficients } \\
\text { Beta }\end{array}$} \\
\hline Model & B & Std. Error & 31,558 & .274 \\
& (Constant) & 347,89 & 2,909 & -.326 \\
& ROA & $-6,395$ & 1,918 & -.304 \\
\hline TANG & $-5,342$ & 0.190 &
\end{tabular}

Konstanta (a) sebesar 347,89 memiliki arti apabila Profitabilitas, Struktur Aktiva, Likuiditas memiliki nilai konstan pada angka nol maka nilai Struktur Modal Perusahaan akan meningkat sebesar 347,89 satuan. Koefisien regresi variabel Profitabilitas sebesar $-6,395$ memiliki arti apabila Profitabilitas meningkat satu satuan maka Struktur Modal Perusahaan menurun sebesar 6,395 satuan dengan asumsi variabel lainnya konstan.

Koefisien regresi variabel Struktur Aktiva sebesar -5,342 memiliki arti apabila struktur aktiva meningkat satu satuan maka Struktur Modal Perusahaan menurun sebesar 5,342 satuan dengan asumsi variabel lainnya konstan. Koefisien regresi variabel Likuiditas sebesar $-0,463$ memiliki arti apabila Likuiditas meningkat satu satuan maka Struktur Modal Perusahaan menurun sebesar 0,463 satuan dengan asumsi variabel lainnya konstan.

Hasil uji koefisien determinasi dapat dilihat pada Tabel 4. Berdasarkan Tabel 4 dapat diamati nilai adjused $\mathrm{R}^{2}$ sebesar 0,287 berarti $28,7 \%$ perubahan (naik turun) pada Struktur Modal Perusahaan yang dipengaruhi oleh Profitabilitas, Likuiditas, 
Struktur Aktiva dan pertumbuhan biaya, sementara sisanya sejumlah 71,3\% dipengaruhi oleh faktor-faktor lain diluar penelitian ini.

Tabel 4.

Hasil Uji Koefisien Determinasi

\begin{tabular}{|c|c|c|c|c|}
\hline Model & $\mathbf{R}$ & R Square & $\begin{array}{l}\text { Adjusted R } \\
\text { Square }\end{array}$ & $\begin{array}{c}\text { Std. Error of the } \\
\text { Estimate }\end{array}$ \\
\hline 1 & $.572^{\mathrm{a}}$ & .328 & .287 & 60.23752 \\
\hline
\end{tabular}

Uji statistik F merupakan uji yang bertujuan untuk menilai kelayakan model regresi yang terbentuk. Uji ini dilakukan dengan melihat signifikansi pada tabel ANOVA dengan menggunakan program SPSS. Apabila nilai signifikansi ANOVA $<\alpha=0,05$, maka model dalam penelitian ini dapat dikatakan layak. Hasil uji signifikan simultan $\mathrm{F}$ dapat dilihat pada tabel 5.

Tabel 5.

Hasil Uji Signifikansi Simultan F

\begin{tabular}{llrrrrr}
\hline Model & \multicolumn{1}{c}{$\begin{array}{c}\text { Sum of } \\
\text { Squares }\end{array}$} & Df & Mean Square & F & Sig. \\
\hline 1 & Regression & 88356,296 & 3 & 29452,099 & 8.117 & $.000^{\text {a }}$ \\
& Residual & 181427,9 & 50 & 3628,559 & & \\
& Total & 269784,2 & 53 & & & \\
\hline
\end{tabular}

Sumber: Data diolah, 2018

Berdasarkan Tabel 5. di atas dapat dilihat nilai signifikan $\mathrm{F}$ yakni 0,000 kurang dari $0,05(0,000<0,05)$, berarti Profitabilitas, Struktur Aktiva, dan Likuiditas secara simultan berpengaruh terhadap Struktur Modal Perusahaan serta model layak untuk digunakan.

Uji statistik $\mathrm{t}$ digunakan untuk menguji seberapa jauh pengaruh variable independen yang digunakan dalam penelitian ini secara individual dalam menerangkan variable independen.

Uji statistik t dapat di ketahui dengan melihat hasil regresi yang dilakukan dengan program SPSS, yaitu dengan membandingkan tingkat signifikansi dengan 
$\alpha=0.05$. Apabila tingkat signifikansi $\mathrm{t}<\alpha=0.05$ maka $\mathrm{H}_{0}$ ditolak, dan sebaliknya jika tingkat signifikansi $\mathrm{t}>\alpha=0.05$ maka $\mathrm{H}_{0}$ diterima. Hasil uji signifikan parsial t dapat dilihat pada Tabel 6 .

Tabel 6.

Hasil Uji Signifikansi Parameter Individual

\begin{tabular}{|c|c|c|c|c|c|}
\hline \multirow[b]{2}{*}{ Model } & \multicolumn{2}{|c|}{$\begin{array}{l}\text { Unstandardized } \\
\text { Coefficients }\end{array}$} & \multirow{2}{*}{$\begin{array}{l}\text { Standardized } \\
\text { Coefficients }\end{array}$} & \multirow[t]{2}{*}{$\mathrm{T}$} & \multirow[t]{2}{*}{ Sig. } \\
\hline & B & Std. Error & & & \\
\hline (Constant) & 347,89 & 31,558 & & 11,024 & .000 \\
\hline ROA & $-6,395$ & 2,909 & .274 & $-2,198$ & .033 \\
\hline TANG & $-5,342$ & 1,918 & -.326 & $-2,786$ & .008 \\
\hline $\mathrm{CR}$ & -0.463 & 0.190 & -.304 & $-2,432$ & .019 \\
\hline
\end{tabular}

Sumber: Data diolah, 2018

Berdasarkan Tabel 6. dapat dilihat bahwa Profitabilitas memiliki nilai $\beta_{1}$ sebesar $-6,395$ bernilai negatif serta besar signifikansi 0,033 lebih kecil dibandingkan dengan 0,05 maka $\mathrm{H}_{0}$ ditolak dan $\mathrm{H}_{1}$ diterima, dengan kata lain Profitabilitas berpengaruh negatif terhadap struktur modal. Hasil penelitian ini sejalan dengan hipotesis yang ditarik dan beberapa penelitian terdahulu. Nanda dan Retnani (2017), Antoni (2016), Nurrohim (2008), Oino (2015), Gamaliel (2015) yang menyatakan bahwa profitabilitas berpengaruh negatif terhadap struktur modal.

Pengaruh ini mengartikan bahwa semakin tinggi profitabilitas perusahaan maka struktur modal perusahaan akan menurun. Perusahaan yang memiliki profitabilitas meningkat, maka akan meningkatkan dana internal perusahaan. Meningkatnya dana internal perusahaan akan menyebabkan perusahaan cenderung menggunakan dana internal untuk pendanaan operasi perusahaan. Peningkatan penggunaan modal internal akan menurunkan total liabilitas, sehingga struktur modal perusahaan akan menurun. 
Berdasarkan Tabel 6. dapat dilihat bahwa Struktur Aktiva memiliki nilai $\beta_{2}$ sebesar -5,342 yang bernilai negatif serta besar signifikansi 0,008 lebih kecil dibandingkan dengan 0,05 maka $\mathrm{H}_{0}$ ditolak dan $\mathrm{H}_{2}$ diterima, dengan kata lain Struktur aktiva berpengaruh terhadap struktur modal pada perusahaan sub sektor konstruksi bangunan di BEI namun tidak berpengaruh positif melainkan berpengaruh negatif.

Hasil yang didapatkan dari hasil uji statistik ini tidak sejalan dengan arah dari hipotesis awal, namun diperkuat dengan beberapa hasil dari penelitian terdahulu. Rofiqoh (2014), Nursatyani (2014), Mandagi (2015), Nasution (2017), dan Koralun (2013) menyatakan bahwa struktur aktiva berpengaruh negatif terhadap struktur modal sehingga apabila terjadi peningkatan struktur aktiva maka akan terjadi penurunan pada struktur modal perusahaan sub sektor konstruksi bangunan di BEI.

Penurunan struktur aktiva akan menyebabkan peningkatan struktur modal pada perusahaan sub sektor konstruksi bangunan di BEI. Ketika perusahaan meningkatkan aktiva tetapnya akan mengurangi minat perusahaan mencari dana eksternal karena perusahaan memiliki dana internal yang tinggi untuk pembiayaan investasinya. Perusahaan yang memiliki aktiva tetap yang tinggi atas total aktivanya cenderung mengalokasikan dananya pada namun ketika perusahaan mengurangi proporsi struktur aktivanya akan meningkatkan minat perusahaan dalam mencari pendanaan atau bantuan dana dari pihak eksternal.

Berdasarkan Tabel 6. dapat dilihat bahwa Likuiditas memiliki nilai $\beta_{3}$ sebesar $-0,463$ yang bernilai negatif serta besar signifikansi 0,019 lebih kecil dibandingkan dengan 0,05 maka $\mathrm{H}_{0}$ ditolak dan $\mathrm{H}_{3}$ diterima, sehingga dapat disimpulkan bahwa 
likuiditas berpengaruh negatif terhadap struktur modal pada perusahaan sub sektor konstruksi bangunan di BEI. Hasil uji ini sudah sesuai dengan hipotesis awal dan didukung dengan beberapa hasil penelitian terdahulu. Cahyani (2017), Widayanti (2016), Munawar (2009), Ratri (2017), Bhattarai (2016) dan Ghasemi (2016) menyatakan bahwa likuiditas berpengaruh negatif terhadap struktur modal.

Pengaruh ini memberikan arti bahwa semakin tinggi tingkat likuiditas akan dengan signifikan menurunkan tingkat struktur modal perusahaan sub sektor konstruksi bangunan di BEI. Sebaliknya apabila semakin rendah tingkat likuiditas akan dengan signifikan meningkatkan tingkat struktur modal perusahaan sub sektor konstruksi bangunan di BEI. Perusahaan yang mampu membayar kewajiban jangka pendeknya tepat waktu, memiliki dana internal yang mencukupi untuk pendanaan perusahaan. Ketika perusahaan memiliki dana internal yang cukup bagi pendanaan perusahaan, maka minat perusahaan dalam pendanaannya akan cenderung pada pendanaan internal. Tingginya dana internal menyebabkan perusahaan lebih menggunakan pendanaan internal dibandingkan dengan dana eksternal.

Pengujian regresi linear berganda pada variabel bebas dan terikat telah dilakukan pada analisis data diatas. Uji-uji yang dilakukan bertujuan untuk mengetahui besarnya pengaruh variabel bebas pada variabel terikat. Berikut merupakan penjelasan dari pengaruh antar variabel tersebut. Beberapa hasil penelitian yang dilakukan dengan uji statistik, tidak semuanya mendapatkan hasil yang sejalan dengan hipotesis. Perusahaan cenderung untuk mendanai investasinya dengan cash flow yang dihasilkan dari internal dan ekuitas internal. Apabila 
dibutuhkan dana eksternal, hutang akan dipilih oleh perusahaan dari pada ekuitas karena kurang tunduk pada hasil evaluasi (Abosede, 2012).

Seluruh jenis pendanaan perusahaan didasari oleh risiko yang nantinya akan ditanggung oleh perusahaan. Risiko ini merupakan prefrensi perusahaan saat memilih pendanaan perusahaan. Perusahaan yang cenderung menggunakan dana internal dari hasil memanfaatkan aktivanya cenderung tidak memerlukan dana eksternal yang tinggi. Perusahaan dengan struktur modal yang lebih mengandalkan dana internal juga memberikan kemandirian dari perusahaan untuk berusaha mencari dana internal yang lebih tinggi sehingga mampu melakukan seluruh keputusan manajemen keuangan perusahaan.

Berdasarkan hasil uji statistik yang dilakukan, seluruh variabel menerapkan salah satu teori struktur modal yakni pecking order theory. Teori tersebut menyarankan perusahaan untuk menggunakan dana internalnya sebagai pendanaan primer dalam operasinya. Alasan lain yang memperkuat pengaruh seluruh variabel yang diuji terhadap struktur modal juga disebabkan oleh adanya peraturanperaturan yang dibuat oleh pemerintah.

\section{SIMPULAN DAN SARAN}

Berdasarkan hasil yang telah dipaparkan diatas, simpulan yang dapat ditarik dari penelitian ini adalah: Profitabilitas berpengaruh negatif terhadap Struktur Modal Perusahaan. Hal ini berarti apabila Profitabilitas semakin meningkat maka akan terjadi penurunan dari Struktur Modal Perusahaan. Berlaku sebaliknya saat profitabilitas menurun makan akan terjadi peningkatan struktur modal perusahaan sub sektor konstruksi bangunan di BEI. Tingginya dana internal perusahaan yang 
didapatkan dari profitabilitas sehingga mampu mendanai investasi perusahaan dengan risiko yang lebih rendah, maka perusahaan akan cenderung menggunakan pendanaan internal dibandingkan eksternal.

Struktur Aktiva berpengaruh negatif terhadap Struktur Modal Perusahaan. Hal ini berarti apabila Struktur Aktiva semakin meningkat maka struktur modal perusahaan semakin menurun. Berlaku sebaliknya apabila Struktur Aktiva semakin menurun, akan meningkatkan struktur modal perusahaan sub sekttor konstruksi bangunan di BEI. Ketika perusahaan memiliki aktiva tetap yang tinggi, maka perusahaan akan cenderung menggunakan pendanaan internalnya dibandingkan pendanaan dari pihak eksternal untuk membiayai investasinya. Likuiditas berpengaruh negatif terhadap Struktur Modal Perusahaan. Hal ini berarti apabila Likuiditas semakin meningkat maka akan memengaruhi penurunan dari struktur modal perusahaan sub sektor konstruksi bangunan di BEI. Sebaliknya dengan likuiditas yang menurun akan mempengaruhi peningkatan struktur modal perusahaan. Kemampuan perusahaan yang tinggi dalam melunasi kewajiban jangka pendeknya, dapat disebabkan karena perusahaan memiliki dana internal yang tinggi. Kondisi ini menyebabkan perusahaan akan cenderung menggunakan dana internalnya dibandingkan dana dari pihak eksternal untuk investasinya.

Saran yang dapat diberikan untuk perusahaan adalah perusahaan diharapkan mengambil keputusan mengenai struktur modal dengan melihat ketiga variabel ini. Penggunaan dana internal perusahaan dalam mendanai keputusan perusahaan lebih memberikan keuntungan kepada perusahaan ketika negara sedang dalam kondisi tidak menguntungkan dan beberapa hal lainnya. Terdapat sejumlah 71,3\% faktor- 
faktor lain diluar penelitian ini yang merupakan faktor yang dapat mempengaruhi struktur modal. Peneliti selanjutnya diharapkan dapat memenuhi persentase ini agar perusahaan dapat lebih melihat secara keseluruhan pengaruh dari variabel penentu struktur modal.

\section{REFERENSI}

Abosede, A. J. (2012). Pecking Order Theory of Capital Structure : Another Way To Look At It. Journal of Business Management and Applied Economics, 4(5), $1-11$.

Acaravci, S. K. (2015). The determinants of capital structure: Evidence from the Turkish manufacturing sector. International Journal of Economics and Financial Issues, 5(1), 158-171. https://doi.org/10.1016/j.chieco.2005.02.007

Alarussi, A. S., \& Alhaderi, S. M. (2018). Factors Affecting Profitability in Malaysia. Journal of Economic Studies, 45(3), 442-458. https://doi.org/https://doi.org/10.1108/JES-05-2017-0124

Alipour, M., Mohammadi, M. F. S., \& Derakhshan, H. (2015). Determinants of Capital Structure: an Empirical Study of Firms in Iran. Internation Journal of Law and Management, 57(1), 53-83. https://doi.org/10.1108/MBE-09-20160047

Anggiani, S. (2018). Kewirausahaan Pola Pikir, Pengetahuan, Dan Keterampilan. Jakarta: Prenadamedia.

Antoni, Chandra, C., \& Susanti, F. (2016). Faktor-Faktor yang Mempengaruhi Struktur Modal Peusahaan Manufaktur di Bursa Efek Indonesia. Jurnal Benefita, 1(2), 78-94.

Armelia, S., \& Ruzikna. (2016). Pengaruh Ukuran Perusahaan, Profitabilitas, Likuiditas dan Struktur Aktiva terhadap Struktur Modal Perusahaan Manufaktur Go Publik. JOM FISIP, 3(2), 1-15.

Bambang, R. (2008). Dasar-dasar Pembelanjaan Perusahaan. Yogyakarta: GPFE.

Batubara, R. A. P., Topowijono, \& Z.A., Z. (2017). Pengaruh Struktur Aktiva, Ukuran Perusahaan, Dan Profitabilitas Terhadap Struktur Modal (Studi Pada Perusahaan Makanan dan Minuman yang Terdaftar di Bursa Efek Indonesia Tahun 2012-2015) . Jurnal Administrasi Bisnis, 50(4), 1-9.

Bhattarai, Y. R. (2016). Effect of Liquidity on the Capital Structure of Nepalese Manufacturing. International Journal of Marketing \& Financial Management, 4(3), 1-14. 
Bhawa, I. B. M. D., \& Sangging, M. R. D. (2015). Pengaruh Ukuran Perusahaan, Likuiditas, Profitabilitas, Dan Risiko Bisnis Terhadap Struktur Modal Perusahaan Farmasi. Jurnal Manajemen, 4(7), 1949-1966. https://doi.org/ISSN:2302-8912

Brigham, E. F., \& Houston, J. F. (2016). Fundamentals of Financial Management (Concise Ed). Boston: Cengage Learning.

Cahyani, N. I., \& Handayani, N. (2017). Pengaruh Profitabilitas , Likuiditas, Size, Kepemilikan Institusional, Dan Tangibility Terhadap Struktur Modal. Jurnal Ilmu Dan Riset Akuntansi, 6(2), 614-630.

Chiang, Y.-H., Cheng, E. W. L., \& Lam, P. T. I. (2010). Epistemology of capital structure decisions by building contractors in Hong Kong Yat-Hung. Construction Innovation, 10(3), 329-345. https://doi.org/http://dx.doi.org/10.1108/MRR-09-2015-0216

Damayanti, N. P. D. (2017). Pengaruh Ukuran Perusahaan, Profitabilitas, dan Risiko Bisnis terhadap Struktur Modal pada Perusahaan Manufaktur di BEI. E-Jurnal Manajemen Unud, 6(10), 5775-5803. https://doi.org/https://ojs.unud.ac.id/index.php/Manajemen/article/view/3311 0

De Wet, J. (2006). Determining the optimal capital structure: a practical contemporary approach. Meditari Accountancy Research, 14(2), 1-16. https://doi.org/10.1108/10222529200600009

Deesomsak, R., Paudyal, K., \& Pescetto, G. (2004). The determinants of capital structure: evidence from the Asia Pacific region. Journal of Multinational Financial Management, 14(4-5), 387-405. https://doi.org/https://doi.org/10.1016/j.mulfin.2004.03.001

Deviani, Y. M., \& Sudjarni, L. K. (2018). Pengaruh Tingkat Pertumbuhan,Struktur Aktiva,Profitabilitas, Dan Likuiditas Terhadap Struktur Modak Perusahaan Pertambangan Di BEI. E-Jurnal Manajemen Unud, 7(3), 1222-1254.

Dewi, N. K. S. M., \& Badjra, I. B. (2014). Pengaruh Likuiditas, Profitabilitas, Tangibility Assets, Ukuran Perusahaan Dan Pajak Terhadap Struktur Modal. Jurnal Ekonomi Dan Bisnis, 3(10), 3017-3033.

Dewi, N. K. T. S., \& Dana, I. M. (2017). Pengaruh Growth Opportunity, Likuiditas, Non-Debt Tax Shield dan Fixed Asset Ratio terhadap Struktur Modal. EJurnal Manajemen Unud, 6(2), 772-801.

Fahmi, I. (2018). Pengantar Manajemen Keuangan. (M. A. Djalil, Ed.). Bandung: Alfabeta.

Farisa, N. A., \& Widati, L. W. (2017). Analisa Profitabilitas, Likuiditas, Pertumbuhan Penjualan, Struktur Aktiva Dan Kebijakan Dividen Terhadap 
Struktur Modal. In Prosiding Seminar Nasional Multi Disiplin Ilmu \& Call For Papers UNISBANK Ke-3 (SENDI_U 3) 2017 (pp. 640-649).

Gamaliel, J., \& Sudjarni, L. K. (2015). Pengaruh Profitabilitas, Ukuran Perusahaan Dan Struktur Aktiva Terhadap Struktur Modal Pada Perusahaan Transportasi Di Bursa Efek Indonesia. E-Jurnal Manajemen Universitas Udayana, 4(1), $59-74$.

Ghasemi, M., \& Hisyam Ab Razak, N. (2016). The Impact of Liquidity on the Capital Structure: Evidence from Malaysia. International Journal of Economics and Finance, 8(10), 130. https://doi.org/10.5539/ijef.v8n10p130

Gill, A., \& Biger, N. (2011). The Effect of Capital Structure on Profitability: Evidence from the United States. International Journal of Management, 28(4), $1-3$.

https://doi.org/http://eserv.uum.edu.my/docview/902631498?accountid=4259 9

Harc, M. (2015). The relationship between tangible assets and capital structure of small and medium-sized companies in Croatia. Ekonomski Vjesnik, 28, 213224. https://doi.org/10.1016/j.intimp.2013.02.010

Irdiana, S. (2016). Analisis Faktor-Faktor yang Mempengaruhi Struktur Modal pada Perusahaan Katagori Saham Blue Chips di Bursa Efek Indonesia Periode Tahun 2011-2014. Jurnal Penelitian Ilmu Ekonomi WIGA, 6(1), 15-26. https://doi.org/10.1016/j.pscychresns.2005.10.006

Juliantika, N. L. A. A. M., \& Dewi, M. R. (2017). Pengaruh Profitabilitas, Ukuran Perusahaan, Likuiditas, dan Risiko Bisnis terhdap Struktur Modal pada Perusahaan Property dan Real Estate. E-Junal Manajamen Unud, 6(6), 31683195. https://doi.org/022/9

Kariyoto. (2018). Manajemen Keuangan Konsep dan Implementasi. Malang: UB Press.

Kepakisan, I. D. A. K. (2015). Pengaruh Struktur Aktiva, Tingkat Pertumbuhan Penjualan, dan Profitabilitas Terhadap Struktur Modal. E-Jurnal Manajemen Universitas Udayana, 4(1), 290-303.

Kesuma, A. (2009). Analisis Faktor yang Mempengaruhi Struktur Modal Serta Pengaruhnya Terhadap Harga Saham Perusahaan Real Estate yang Go Public di Bursa Efek Indonesia. Jurnal Manajemen Dan Kewirausahaan, 11(1), 3845 .

Koralun, J., \& Bereźnicka. (2013). How Does Asset Structure Correlate with Capital Structure? - Cross-Industry and Cross-Size Analysis of the EU Countries. Universal Journal of Accounting and Finance, 1(1), 19-28. https://doi.org/10.13189/ujaf.2013.010103 
Liestyasih, L. P. E., \& Yadnya, I. P. (2015). Pengaruh Operating Leverage, Ndts, Struktur Aktiva, dan Growth terhadap Struktur Modal. E-Jurnal Manajemen Universitas Udayana, 4(2), 607-621.

Madhavilatha, A. (2016). A Study on Capital Structure and Profitability of Cement Companies in Telangana. Journal of Commerce \& Management Thought, 7(4), 795-817.

Mandagi, Y. G. D., Suriguna, P., \& Lina, S. (2015). Faktor-faktor yang Mempengaruhi Struktur Modal pada Perusahaan Real Estate and Property yang Go Public di Bursa Efek Indonesia. Jurnal Ilmiah, 19(1), 28-39. Retrieved from http://ejournal.unri.ac.id/index.php/JE/article/view/798/791

Mandana, I. W. M., Gede, L., \& Artini, S. (2011). Pengaruh Struktur Aktiva, Tingkat Pertumbuhan Penjualan, Profitabilitas, dan Pertumbuhan Perusahaan terhadap Struktur Modal pada PT. PLN (Persero) Distribusi Bali Periode 20042011. E-Jurnal Manajemen Universitas Udayana, 4(7), 1798-1815.

Miglo, A. (2016). Capital Stucture in the Modern World. Canada: Palgrave Macmillan.

Munawar, A. (2009). Analisis pengaruh aset tetap, likuiditas, ukuran, dan profitabilitas terhadap struktur kapital perusahaan. Jurnal Ilmiah Ranggagading, 9(1), 24-33.

Musthafa. (2017). Manajemen Keuangan. (P. Christian, Ed.) (1st ed.). Yogyakarta: ANDI.

Nanda, D. W., \& Retnani, E. D. (2017). Pengaruh Profitabilitas, Kepemilikan Manajerial, Kepemilikan Institusional dan Risiko Bisnis terhadap Struktur Modal. Jurnal Ilmu \& Riset Akuntansi, 6(3), 945-962.

Nasution, A. A., Siregar, I., \& Panggabean, R. (2017). The Effect of Profitability, Asset Tangibility, Corporate Tax , Non-debt Tax Shield and Inflation upon the Financial Capital Structure of the Manufacturing Companies listed on the Indonesian Stock Exchange. Advances in Economics, Business and Management Research, 36, 65-74.

Novitayanti, C. I. D., \& Rahyuda, H. (2018). Determinan Struktur Modal Berdasarkan Pecking Order Theory pada Perusahaan Sektor Barang Konsumsi Di BEI. E-Jurnal Manajemen Unud, 7(8), 4475-4507. https://doi.org/https://doi.org/10.24843/EJMUNUD.2018.v7.i08.p16

Nugroho, N. C. (2014). Analisis Pengaruh Profitabilitas, Pertumbuhan Penjualan, Ukuran Perusahaan, Dan Umur Perusahaan Terhadap Struktur Modal Usaha Mikro Kecil Dan Menengah Kerajinan Kuningan Di Kabupaten Pati. Management Analysis Journal, 3(2), 6-10. https://doi.org/ISSN 2252-6552

Nurrohim, H. (2008). Pengaruh Profitabilitas, Fixed Asset Ratio, Kontrol 
Kepemilikan Dan Struktur Aktiva Terhadap Struktur Modal Pada Perusahaan Manufaktur Di Indonesia. Sinergi Kajian Bisnis Dan Manajemen, 10(01), 1118. https://doi.org/10.1017/CBO9781107415324.004

Nursatyani, A., Wahyudi, S., \& Syaichu, M. (2014). Analisis Pengaruh Current Ratio, Debt to Equity Ratio, Total Asset Turnover dan Return On Investment Terhadap Dividend Payout Ratio pada Perusahaan Otomotif yang terdaftar di BEI Periode 2009-2011. Jurnal Bisnis Strategi, 23(2), 97-127.

Oino, I., \& Ukaegbu, B. (2015). The impact of profitability on capital structure and speed of adjustment: An empirical examination of selected firms in Nigerian Stock Exchange. Research in International Business and Finance, 35, 111121. https://doi.org/10.1016/j.ribaf.2015.03.004

Pertiwi, N. K. N. I., \& Darmayanti, N. P. A. (2018). Pengaruh Profitabilitas, Likuiditas, Struktur Aktiva, dan Kebijakan Dividen terhadap Struktur Modal Perusahaan Manufaktur Di BEI. E-Jurnal Manajemen Unud, 7(6), 3115-3143.

Radjamin, I. J. P., \& Sudana, I. M. (2014). Penerapan Pecking Order Theory Dan Kaitannya Dengan Pemilihan Struktur Modal Perusahaan Pada Sektor Manufaktur Di Negara Indonesia Dan Negara Australia. Jurnal Manajemen Bisnis Indonesia, 1(3), 451-468.

Ratri, A. M., \& Christianti, A. (2017). Pengaruh Size, Likuiditas, Profitabilitas, Risiko Bisnis, Dan Pertumbuhan Penjualan Terhadap Struktur Modal Pada Sektor Industri Properti. Jurnal Riset Manajemen Dan Bisnis, 12(1), 13-24.

Rofiqoh, N., \& Kurnia. (2014). Pengaruh Struktur Aktiva, Likuiditas dan Profitabilitas terhadap Struktur Modal Perusahaan. Jurnal Ilmu \& Riset Akuntansi, 3(2), 1-15.

Samsul, M. (2016). Pasar Modal dan Manajemen Portofolio (2nd ed., p. 508). Jakarta: Erlangga.

Sansoethan, D. K., \& Suryono, B. (2016). Faktor-faktor yang Mempengaruhi Struktur Modal pada Perusahaan Makanan dan Minuman. Jurnal Ilmu \& Riset Akuntansiu Dan Riset, 5(1), 1-11. https://doi.org/ISSN : 2460-0585

Sartono, A. (2014). Manajemen Keuangan:Teori dan Aplikasi (4th ed.). Yogyakarta: BPFE.

Suryaman, Y. A. (2016). Pengruh Profitabilitas, Struktur Aktiva, dan Ukuran Perusahaan terhadap Struktur Modal pada Perusahaan Manufaktor yang Terdaftar di Bursa Efek Indonesia Tahun 2009-2012. Jurnal Profita, (3), 116.

Suweta, N. M. N. P. D., \& Dewi, M. R. (2016). Pengaruh Pertumbuhan Perjualan, Struktur Aktiva, dan Pertumbuhan Aktiva Terhadap Struktur Modal. E-Jurnal Manajemen Unud, 5(8), 5172-5199. https://doi.org/ISSN : 2302-8912 
Tijow, A. P., Sabijono, H., \& TIrayoh, V. Z. (2018). Pengaruh Struktur Aktiva dan Profitabilitas terhadap Struktur Modal pada Perusahaan Sektor Industri Barang Konsumsi yang Terdaftar di Bursa Efek Indonesia. Jurnal Riset Akuntansi Going Conern, 13(3), 477-488.

Tulsian, P. C., \& Tulsian, B. (2016). Financial Management with Quick Revision (For CA-IPC, Group-I) (7th ed.). New Delhi: S Chand and Company Limited.

Utami, L. N. S., \& Widanaputra, A. A. G. P. (2017). Pengaruh Tarif Pajak, Profitabilitas, Likuiditas, dan Ukuran Perusahaan terhadap Struktur Modal Perusahaan Manufaktur di BEI. E-Jurnal Akuntansi Universitas Udayana, 20(1), 352-379.

Vo, X. V. (2017). Determinants of capital structure in emerging markets: Evidence from Vietnam. Research in International Business and Finance, 40, 105-113. https://doi.org/10.1016/j.ribaf.2016.12.001

Wangsawinangun, R. Z. (2014). Penetapan Struktur Modal yang Optimal dalam Upaya Meningkatkan Nilai Perusahaan (Studi Pada PT . Astra International, Tbk dan Anak Perusahaan Tahun 2008-2012 ). Jurnal Administrasi Bisnis, 9(2), 1-8.

Wiagustini, N. L. P. (2014). Manajemen Keuangan. (J. Atmaja, Ed.). Denpasar: Udayana University Press.

Widayanti, L. P., Triaryati, N., \& Abundanti, N. (2016). Pengaruh Profitabilitas, Tingkat Pertumbuhan Perusahaan, Likuiditas, Dan Pajak Terhadap Struktur Modal Pada Sektor Pariwisata. E-Jurnal Manajemen Universitas Udayana, 5(6), 3761-3793.

Yusrianti, H. (2013). Laporan Penelitian Dana Fakultas Ekonomi Unsri 2013. Palembang. 